Miró, A., I. Sabás, and M. Ventura. 2018. Large negative effect of non-native trout and minnows on Pyrenean lake amphibians. Biological Conservation, 218:144-153.

Biological Conservation personalised share link (no sign up, registration or fees are required until February 17, 2018): https://authors.elsevier.com/a/1WIpD1R e 72se

\title{
Large negative effect of non-native trout and minnows on Pyrenean lake amphibians
}

\footnotetext{
Alexandre Miró ${ }^{\mathrm{a},}$, Ibor Sabás ${ }^{\mathrm{a}}$ and Marc Ventura ${ }^{\mathrm{a}}$

${ }^{\mathrm{a} C e n t r e ~ f o r ~ A d v a n c e d ~ S t u d i e s ~ o f ~ B l a n e s, ~ S p a n i s h ~ R e s e a r c h ~ C o u n c i l ~(C E A B-C S I C), ~}$ Integrative Freshwater Ecology Group (IFE), Blanes 17300, Girona, Catalonia, Spain.

*E-mail: alexestanys@gmail.com
} 


\begin{abstract}
High mountain lakes are mostly naturally fishless ecosystems that have received numerous trout introductions over the world. Extensive studies mostly developed in west North America have shown a large negative effect of these introductions on amphibians, although no extensive studies are available from other continents such as Europe. Fish were also introduced extensively in the Pyrenees (southern Europe), mainly trout for angling and minnows for their use as live bait for fishing trout. We studied the effect of non-native trout and minnows on the occurrence of amphibian species inhabiting Pyrenean lentic habitats. Chi-square tests and Generalized Additive Models were applied on a dataset of 12 environmental descriptors from 1739 water bodies surveyed from 2006 to 2016. After accounting for environmental characteristics we found a large negative effect of non-native trout and minnows on Pyrenean amphibians. Trout was negatively associated with four of the six studied species. Since minnows were only introduced in trout present lakes, they were only significant for Rana temporaria, the most distributed amphibian in the area. None of the palatable amphibians have been able to recolonise the lakes where minnow remain as the only fish species indicating a strong negative effect. Minnow is the non-native fish with a higher introduction rate in the mountain range indicating that it might be a threat for other species in the future. Therefore, the control of trout stocking and minnow release in high mountain lakes is necessary to preserve European and worldwide amphibian populations in these ecosystems.
\end{abstract}

\title{
Keywords
}

Amphibian decline; Exotic fish; Freshwater ecology; Habitat characteristics; High mountain lakes; Invasive species

\section{Introduction}

Within mountain regions, amphibians are amongst the most conspicuous native animals of high altitude water bodies (lakes and ponds), where they are threatened by non-native trout, as well as pesticides and emerging diseases (Davidson and Knapp, 2007; Knapp, 2005; Walker et al., 2010). Focussing on non-native trout, northern hemisphere high mountain water bodies are naturally fishless ecosystems due to natural barriers that prevent the colonization of fish species from lower streams or the dispersal between interconnected lakes (Knapp et al., 2001; Pechlaner, 1984). This contrasts with the lakes of the southern hemisphere where they may be colonised by fish of the family Galaxiidae, which are able to climb steep slopes, such as different species of the genus Galaxias that inhabit lakes and creeks up to approximately 2000 m.a.s.l. from Australia and New Zealand (Hardie et al., 2006). However, the highest and remotest mountain lakes of Australia, Tasmania and New Zealand are also naturally fishless (McDowall, 1990), as well as those of South America (Reissig et al., 2006). 
Nowadays many high altitude lakes around the world have suffered trout introductions since the 19th century, mainly for angling purposes (e.g. Christenson, 1977; Wiley, 2003). In addition to trout, minnows have also expanded considerably throughout the twentieth century in the north European lakes of Scotland and Norway, especially in mountain areas, mainly due to the use of minnows as live bait for angling (Maitland and Campbell, 1992; Museth et al., 2007). In the specific case of the Pyrenees, approximately $25 \%$ of the lakes $>0.5$ ha were stocked with trout in historical periods, from some centuries ago until 1950. Since then a further wave of modern introductions has taken place with exotic trout, as well as minnows, affecting between $35 \%$ and $85 \%$ of the lakes $>0.5$ ha depending on the valley (Delacoste et al., 1997; Miró and Ventura, 2013, 2015).

Since the 1990s, several studies have reported strong negative effects of introduced trout on autochthonous amphibians (among other impacts) in high mountain water bodies, especially from North America. Most studies showed that direct trout predation on larvae and adults can lead to the elimination of some native amphibians (e.g. Denoël et al., 2005; Knapp, 2005; Orizaola and Braña, 2006; Tiberti et al., 2016); other studies highlighted competition between introduced trout and adult amphibians for invertebrate prey (Finlay and Vredenburg, 2007) or increases in shared predators leading to increased predation pressure on amphibians (Pope et al., 2008). The impacts of introduced trout can extend beyond the boundaries of individual water bodies in mountain areas and extinguish some amphibians from whole catchments if there are not enough suitable fishless habitats (Pilliod et al., 2010). Nevertheless, the presence of macrophytes or other structural refugees may facilitate coexistence between amphibians and introduced trout (Kenison et al., 2016). Most of the extensive studies are from North America (e.g. Knapp, 2005; Pilliod et al., 2010) where not all species are equally affected by introduced fish. Therefore, similar studies are critically needed from other continents inhabited by species with different evolutionary histories.

While the impact of introduced trout on high mountain lake amphibians has been extensively reported, there is a large gap of knowledge about the role of non-native minnows. Nevertheless, a negative effect may be expected, since minnows and trout have similar diets (Museth et al., 2010) and are causing amphibian declines in lowland lakes (e.g. Denoël et al., 2005). The main objective of this study was to extensively evaluate the effect of non-native trout and minnows on European amphibians present in high mountain water bodies of the Pyrenees. The study also aimed to describe the general habitat associations of the amphibian species, as this information is currently available only for some species and reduced areas (e.g. Montori et al., 2008; Vences et al., 2003).

\section{Materials and Methods}

\subsection{Study area and amphibian survey}


We surveyed 1739 lakes and ponds along the Pyrenean mountain range $\left(2^{\circ} 05^{\prime} \mathrm{W}-3^{\circ} 15^{\prime} \mathrm{E}, 43^{\circ} 18^{\prime}-42^{\circ} 16^{\prime} \mathrm{N}\right)$, representing approximately $30 \%$ of the total number in the range (Fig. 1). A detailed description of Pyrenean lake characteristics is provided in the online Appendix A.

The studied amphibian species comprised three anurans and three urodeles: common frog Rana temporaria Linnaeus, 1758; midwife toad Alytes obstetricans (Laurenti, 1768); common toad Bufo spinosus Daudin, 1803; palmate newt Lissotriton helveticus (Razoumovsky, 1789); fire salamander Salamandra salamandra (Linnaeus, 1758); and Pyrenean newt Calotriton asper (Dugès, 1852), the last of which is endemic to the region. All these species are protected by regional and national legislation in most of the mountain ranges, being forbidden their killing, capture or disturbance, (e.g. Pleguezuelos et al., 2002). Moreover, three of the species are included in the European Directive 92/43/EEC for the conservation of natural habitats and of wild fauna and flora: C. asper, A. obstetricans in Annex IV and R. temporaria in Annex V (European Council, 1992).

The field surveys for amphibian occurrence were conducted during the lakes' ice-free periods from 2006 to 2016. To avoid seasonal variations in species occurrence, as found in some studies of high mountain and boreal lakes (e.g. Knapp, 2005; Laugen et al., 2003), we carried out surveys following altitudinal and temperature gradients, from warmer to colder sites. When non-detection data did not match prior oral or published knowledge, we repeated the survey in the same year or in following years. In addition, and due to the nocturnal habits of C. asper, we resurveyed in night time 48 water bodies $(2.7 \%$ of the total) within the known distribution area of the species (e.g. Martínez-Rica, 1978), torching the entire shoreline from shortly after dusk to shortly after midnight. Nocturnal surveys confirmed that daily surveys detected with sufficient accuracy the species presence in the lakes. In total we conducted 2762 amphibian surveys in the 1739 water bodies studied. A number of 402 lakes or ponds $(23.1 \%$ of the total) were visited in multiple occasions: $16.4 \%$ were surveyed $2-3$ times, $2.1 \%$ were surveyed 4-5 times and 4.6\% were surveyed $>5$ times. Data from all surveys were pooled to determine amphibians' occurrence. In addition, multiple visits from single or several years were used to compute the single-visit detection probability when a species is present in a water body through the software PRESENCE (MacKenzie et al., 2002). The program was run under the assumption that the sites kept the same occupancy for the whole sampling period. We also estimated the accumulated probability of detecting a given species in a water body when the number of visits increase and the species is present. We used the function provided by Wintle et al. (2005). For these calculations we assumed that the probability of detection was the same for all visits and that detections were independent among visits.

We assessed the occurrence of the anurans R. temporaria, A. obstetricans and $B$. spinosus based on the presence/absence of egg masses or larvae, and the occurrence of the urodeles C. asper, L. helveticus and S. salamandra on the presence/absence of at 
least one of the different life stages (eggs, larvae, sub-adults or adults). The occurrence of amphibians was evaluated by visual encounter surveys (Crump and Scott Jr., 1994) of sufficient shore segments (between 10 and 30 depending on the water body perimeter) proportionally distributed for the different substrates found along the perimeter of each water body. Shore segments were $10 \mathrm{~m}$ long, parallel to the shoreline, $2 \mathrm{~m}$ into the water and $2 \mathrm{~m}$ into the next terrestrial strip. When no amphibians were detected in the segments, the entire shoreline of the water body was resurveyed.

\subsection{Environmental descriptors}

To quantify which factors best explain amphibian distribution, we generated a set of 12 variables summarizing the environmental characteristics of the sampled water bodies (Table 1). Field data for environmental variables were collected during the lakes' ice-free periods from 2008 to 2014.

The presence/absence of trout and minnows for most of the studied water bodies was firstly determined on previously collected data from historical documental sources, from interviews with local elderly fishermen or nature reserve wardens, from local reports of fishing or walking societies and from our own previous visual field surveys (Miró and Ventura, 2013, 2015). Those data were validated at each studied water body and nearby streams during the field visits for this study by visual encounter surveys. Visual surveys for fish detection are highly effective in small water bodies ( $<3 \mathrm{~m}$ deep; Knapp, 2005), but also for minnows in any lake size, since they swim preferably in shallow littoral areas to avoid trout predation (Museth et al., 2010). In addition, we performed detailed surveys in a subset of $c a .50$ lakes $>0.5$ ha chosen randomly, using gill nets, funnel traps or scuba diving. Detailed surveys corroborated all the presences/absences for trout or minnow established by previous studies or visual encounter surveys. Nevertheless, two disagreements were recorded regarding to the trout species present.

The dataset of environmental variables included also four standardized descriptors previously used in other studies: geographical location as UTM easting and northing, altitude and surface area of the water body, and littoral and shore habitat characteristics summarized by the first principal component of a PCA. High values of this variable were associated with shallow or flat slope littoral, fine grain littoral substrate and vegetated shores, while low values were associated with moderate to steep slope littoral, coarse grain littoral substrate and bare rocky shores (Table A1 in online Appendix A). Topographic, habitat and connectivity characteristics have previously showed extensive roles for amphibian occurrence in high mountain water bodies (e.g. Knapp, 2005; Orizaola and Braña, 2006; Pilliod et al., 2010; Pope et al., 2008).

We then added to the dataset six other descriptors that according to previous studies we expected to be meaningful for amphibians: existence of refuge areas from fish predation (shallow littoral areas where amphibians can get shelter), $\%$ coverage of the littoral occupied by aquatic vegetation, conductivity, and two binary variables 
aiming to highlight water bodies with adverse features for amphibians such as cold sites with cold water inflow during the summer (e.g. from cold springs or melt-water much colder than expected by the altitude of the water body) and existence of temporary ponds that dry up most of the ice-free seasons. We chose to use a binary variable for these two categories since the use of water temperature would have added noise associated with seasonality or altitude. We accounted for connectivity among water bodies by including the linear distance to the nearest neighbouring occupied water body for each species. This descriptor was built separately for each amphibian species and then corrected for the heterogeneous effect of Pyrenean geology on the density of water bodies. A detailed description of how these variables were obtained is provided in online Appendix A.

\subsection{Statistical analysis}

First of all we compared the occurrence of the different amphibian species with the presence of trout, minnows, both taxa or none of them, by chi-square tests based on contingency tables. We also added a contingency table pooling together all five palatable species: $R$. temporaria, A. obstetricans, C. asper, L. helveticus and $S$. salamandra. Since the dataset contained lakes clearly above some of the species altitudinal distribution limits, we also repeated the chi-square tests excluding the high elevation unsuitable sites above the $90 \%$ of each species occurrence.

Then we investigated the relative importance of non-native trout and minnows on amphibian occurrence, accounting for environmental characteristics, through semiparametric generalized additive models (GAM; Hastie and Tibshirani, 1990; Wood, 2006). For each amphibian species (except S. salamandra as there were too few samples), one GAM of binomial distribution was made, including all descriptors of the dataset (see above). Smooth penalized thin plate regression spline class was used for continuous variables, as they tend to give the best mean square error performance (Wood, 2004). The optimal amount of smoothing was determined by general cross validation error, a method that allowed us to recognize either linear or non-linear relationships with the response variable (Wood, 2008). To account for spatial autocorrelation in habitat features and amphibian populations, we included the smooth function of UTM easting and northing of the water body as a covariate (e.g. Knapp, 2005; Knapp et al., 2003; Pilliod et al., 2010). Since the default estimation of smoothness for both joined UTM terms overfitted the adjustment of the resulting variable compared to the other variables, we constricted its effective degree of freedom by reducing the smoother parameter by 0.5 (Wood, 2004). We determined the relative weight of each variable by dropping it from the model whilst maintaining all other variables and evaluating the resultant change in deviance. To avoid obtaining statistically significant variables despite very weak associations with species presence/absence (due to the large dataset used), predictors were considered to have significant effects only when $P \leq 0.01$ (Knapp, 2005). The relationship between the 
highly significant predictor variables and the probability of the species' occurrence is shown graphically in separate plots. Response curves are based on partial residuals and are standardized to have a mean probability of zero. The response curves are plotted on a log-scale and show the relative influence of the predictor variable on the probability of the species' occurrence. Confidence intervals were calculated by a Bayesian approach to variance estimation, with good coverage probabilities (Marra and Wood, 2012). Before performing the regressions, we examined the dataset for linear dependencies, computing Variance Inflation Factors (VIF) for the whole dataset. All VIF values obtained were below 3-5 (table A2), the threshold indicative of worrisome collinearity for regressions (Zuur et al., 2009). All analyses were performed with $\mathrm{R}$ statistical software (R Core Team, 2016) using the core functions and the packages spatstat (Baddeley et al., 2015), fifer (Fife, 2017) and mgcv (Wood, 2006).

\section{Results}

\subsection{Amphibian and fish occurrence}

Among the 6 amphibian species present in Pyrenean water bodies, R. temporaria was the most widely distributed (Fig. 1), being found in 1037 of the 1739 water bodies (59.6\%). A. obstetricans was found in 64 sites (3.7\%), B. spinosus in $47(2.7 \%), C$. asper in 40 (2.3\%), L. helveticus in $65(3.7 \%)$ and S. salamandra in $11(0.6 \%)$ (Fig. 1). The probability of detection after a single visit given presence was: $0.78( \pm 0.01 \mathrm{SE})$ for $R$. temporaria, $0.84( \pm 0.03 \mathrm{SE})$ for $A$. obstetricans, $0.75( \pm 0.04 \mathrm{SE})$ for $B$. spinosus, $0.63( \pm 0.04 \mathrm{SE})$ for $C$. asper, $0.74( \pm 0.03 \mathrm{SE})$ for L. helveticus and $0.76( \pm 0.09 \mathrm{SE})$ for $S$. salamandra. In addition, all species reached detection probabilities greater than 0.98 after the third survey except $C$. asper, which obtained a value of 0.95 after three visits (Fig. A1).

Among the 1739 surveyed water bodies, 359 (20.9\%) had introduced fish. Nonnative trout were observed in 306 water bodies (17.6\%) and non-native minnows in 203 (11.7\%). The number of water bodies with only trout or minnows was $156(9 \%)$ and 53 (3\%) respectively, while $150(8.6 \%)$ had both types of fish coexisting. Gill nets, funnel traps and scuba diving surveys confirmed that brown trout (Salmo trutta) was by far the most common trout species (16\% of the water bodies), while rainbow trout (Oncorhynchus mykiss) and brook trout (Salvelinus fontinalis) were found rarely $(<3 \%)$.

\subsection{Fish effect}

Non-native fish presence/absence showed a large effect on amphibian's occurrence in Pyrenean high mountain water bodies. Both trout and minnows had a substantial negative effect on $R$. temporaria. This species had significantly higher occurrence in fishless water bodies than in sites with trout or minnows or both types of fish (Fig. 2). The GAM developed for the occurrence of $R$. temporaria resulted with a weight of trout presence more than twice the explained deviance $(20.8 \%)$ of any other 
variable, together with a considerable importance (7.1 of explained deviance) of minnow presence (Table 2; Fig. 3).

A. obstetricans, C. asper, L. helveticus and S. salamandra showed no significant differences for the probability of occurrence between sites where non-native trout or minnows were present versus absent (Fig. 2). Nevertheless, after accounting for environment features (GAMs), trout presence was significant and negatively related to the occurrence of A. obstetricans, C. asper and L. helveticus (Table 2; Fig. 3 and 4). Neither trout nor minnow presence/absence were significant for explaining the occurrence of $S$. salamandra, although all 11 presences detected for this species were in fishless water bodies (Fig. 2). In contrast, B. spinosus had significantly higher occurrence in lakes with trout or minnows than in fishless lakes (Fig. 2), although after accounting for environmental characteristics the presence/absence of fish was not significant (Table 2; Fig. 3).

The analyses of all five palatable species pooled together showed significantly higher occurrence in fishless water bodies than in sites with trout or minnow or both type of fish (Fig. 2). In addition, chi square tests excluding the high elevation unsuitable water bodies gave the same pattern of results of the ones with the entire dataset.

\subsection{Environmental variables}

The GAM developed for modelling the occurrence of the five amphibian species resulted with other significant environmental variables apart from non-native fish (Table 2; Fig. 3 and 4). The presence of predation refuge in the water body was linked to higher occurrences of three species: $R$. temporaria, $A$. obstetricans and $C$. asper (Table 2; Fig. 3 and 4). Broadly, the variables altitude and cold site showed the association between low water temperature and low occurrence of amphibians, while habitat characteristics (surface area, soft habitat PC1, aquatic vegetation, water conductivity and temporary pond) highlighted the different habitat preferences of the different amphibian species (Table 2; Fig. 3 and 4). The connectivity variable (distance to the nearest pond occupied) had a positive relationship with the occurrence of all amphibian species. Geographical location (UTM coordinates) showed higher probability of occurrence of $R$. temporaria in the south east Pyrenees and $A$. obstetricans in the western Pyrenees (Table 2; Fig. 3, 4 and A2).

\section{Discussion}

\subsection{Fish impact}

Some extensive studies mostly developed in western North America during recent decades have shown negative effects of non-native trout on some autochthonous amphibians in high mountain lakes (e.g. Knapp, 2005; Pilliod et al., 2010). Our extensive study is also showing important negative effects of non-native trout, but also of non-native minnows on European amphibians in high mountain lakes. Non-native trout was significant and negatively associated with four out of the five Pyrenean 
species (the sixth species, S. salamandra, is very rare in high mountain lakes). This proportion of species affected is greater than the proportion found in western North America where approximately half of the species, mostly anurans, have been shown to be negatively impacted by trout (e.g. Knapp, 2005).

In the Pyrenees, with the exception of B. spinosus, amphibians are almost absent from water bodies with non-native fish. Indeed, B. spinosus was the only species present in almost half of the lakes and ponds where amphibians and fish shared the main body of the lake (e.g. excluding littoral refugees) $(n=19)$. These results are consistent with those obtained by previous studies such as those from lowland lakes and ponds (Indermaur et al., 2010), or high altitude water bodies, which are well known for their poorly structured habitat and high water transparency (Knapp, 2005; Pilliod et al., 2010; Tiberti and von Hardenberg, 2012). The lack of impact that we found on B. spinosus can be explained by the unpalatability and toxicity of this species' tadpoles (Benard and Fordyce, 2003). In fact, all species of the genus Bufo studied so far seem to benefit from the presence of fish (Indermaur et al., 2010; Orizaola and Braña, 2006).

We found that trout was a significant variable for a greater number of species than minnows (four and one respectively). This result might lead to the erroneous conclusion that trout has a more adverse impact than minnows. Trout was the first fish species introduced in Pyrenean lakes, dating back to at least the middle ages (Miró and Ventura, 2013), while minnows have been introduced as live bait for fishing trout only a few decades ago (Miró and Ventura, 2015). Therefore only in lakes where trout was previously present. This suggests that the negative effect of minnows is masked by the presence of trout, which already eradicated most of the species before minnows were introduced in the lakes. In fact, although there are only few lakes (ca. 30 in the present study) where trout has disappeared and minnows remain as the only fish species, in any of them amphibians other than $B$. spinosus have been able to recolonise these lakes. There is little literature about the impact of minnows on high mountain lakes. However, it has been reported that they can have an impact at least as strong as trout in the case of zooplankton (Schabetsberger et al., 2009). Since most of the studied lakes with minnows also have trout ( $\mathrm{n}=156$ in this study) it is likely that the lack of significance of minnow for some species such as L. helveticus or S. salamandra, can be due to the low number of occurrences found (Fig. 2). This is also suggesting that further studies with more balanced datasets are needed to properly test minnow effects on amphibian species with low occurrence.

\subsection{Environmental characteristics}

Altitude of the water body was significant for four species being in most of them negatively correlated with species occurrences. It was especially important for $B$. spinosus and L. helveticus. Since altitude is mostly linked to temperature in high mountains (Thompson et al., 2009), this is suggesting that higher thermal requirements of both species are largely constraining their distribution in high mountain lakes. This 
may explain why we only found $B$. spinosus at relatively low altitudes, almost always below $2200 \mathrm{~m}$. This finding is consistent with those obtained by previous studies from the central part of the Pyrenees, which only found B. spinosus below $2160 \mathrm{~m}$ (Vences et al., 2003). Nevertheless, the altitudinal limit of this species may also be influenced by the high sensitivity of its tadpoles to UV-B radiation (Häkkinen et al., 2001). The model of $R$. temporaria also selected altitude, but in this case, the highest probability of finding the species was at intermediate values. The study of Vences et al. (2003) in the central Pyrenees, also found a polynomic relationship between altitude and the log probability of $R$. temporaria occurrence. In the Pyrenees, intermediate altitudes are those with the higher proportion of ponds with respect to lakes. Therefore, since $R$. temporaria is commonly found in ponds or small lakes where fish are not present, a higher preference for intermediate altitudes is to be expected. Eventually, the presence of cold water inflow during the summer (from cold springs or late melt-water), was the second variable in terms of explained deviance and negatively associated with $R$. temporaria occurrence. This species is known to select microhabitats with favourable temperatures (Kohler et al., 2011), so its discrimination against excessively cold sites is to be expected.

Conductivity appeared to be important for $C$. asper and especially for $A$. obstetricans. The minimum conductivity for ponds and lakes with A. obstetricans was $10.4 \mu \mathrm{S} / \mathrm{cm}$ (95\% of the species' occurrences). These results contrast with the much lower conductivity tolerated by $R$. temporaria or L. helveticus, which are found at conductivities as low as 3.9 and $3.2 \mu \mathrm{S} / \mathrm{cm}$ respectively $(95 \%$ of the species' occurrence). Several physiological mechanisms are known in amphibians to keep internal osmolality under control in changing environments. Aquaporin and other channels allow hydro mineral transport through the epithelium and other membranes, and some organs, such as the urinary bladder and kidneys, are involved in amphibian homeostasis (Suzuki and Tanaka, 2009). However, our results show that amphibian species have different tolerances to water conductivity in the field, with A. obstetricans the least tolerant to low values. The distribution of $A$. obstetricans is also constrained by the impossibility to use temporary ponds since this is a species that require several summers to complete the larval period in high mountain areas. Similarly to Rana muscosa, inhabiting high mountain lakes of North America (Knapp, 2005). These specific ecological requirements, in addition to fish presence, result in substantial limitations of suitable habitat for A. obstetricans, a species which is also highly threatened by chytridiomycosis in the region (Walker et al., 2010).

The PC1 of the littoral and shore habitats (soft habitat PC1) was selected by two models, but showed different sign. While $R$. temporaria was related to shallow or flat littoral, fine grain littoral and vegetated shores, C. asper was associated with littoral with moderate to steep slopes, coarse grain littoral and rocky shores. Previous studies from high mountain lakes also showed that, after accounting for fish presence, some urodeles such as Taricha torosa sierrae or Ambystoma macrodactylum are more 
frequent on coarse-grain littoral substrates (e.g. Knapp, 2005). Geographical location was significant for $R$. temporaria, but was the most important variable explaining $A$. obstetricans variance, showing the importance of spatial autocorrelation for the latter, which is widely distributed in the western Pyrenees but scarcer in the eastern part. Similar spatial patterns have been found in previous studies for some amphibians (e.g. Knapp, 2005; Pilliod et al., 2010). The distance to the nearest pond occupied was significant for all the five species modelled, and is also highlighting the positive synergy given by the high abundance of nearer suitable habitats, as has been shown in many studies about amphibians (e.g. Hartel et al., 2010).

\subsection{Habitat fragmentation and conservation implications}

Our results show that suitable amphibian habitat in high mountain lakes is highly fragmented by natural factors for all amphibian species. The high presence of introduced fish (i.e. $20.6 \%$ in our dataset) is locally making many water bodies unsuitable and thus, markedly increasing the degree of isolation of breeding sites. In general, it has been reported that species may be negatively affected by habitat fragmentation, when suitable habitats have become too isolated; either by natural or anthropogenic causes (e.g. Fischer and Lindenmayer, 2007). This fragmentation may lead to loss of fitness through inbreeding or local extinction through stochastic effects (Griffiths and Williams, 2000). This negative effect may still be stronger on species with a small geographic distribution ranges (Sodhi et al., 2008) such as C. asper, which should be urgently targeted for conservation.

\section{Conclusions}

After accounting for environmental characteristics, we found an important negative effect of non-native trout on the occurrence of four of the six Pyrenean amphibians studied: R. temporaria, A. obstetricans, C. asper and L. helveticus. Nonnative minnows were negatively linked with the occurrence of $R$. temporaria, the most widely distributed amphibian in the mountain range. The recent expansion of minnows and their uncontrolled introductions is certainly an issue of concern that may threat other species in the future, since this is currently the most expanding non-native fish in the mountain range. Our results clearly show that effective amphibian conservation needs the implementation of management policies of high mountain water bodies incorporating restrictive criteria about trout stocking and the use of minnows as live-bait for angling.

\section{Acknowledgements}

The authors would like to acknowledge all people who helped us during the field work and the facilities given in the field work by management teams, employees and nature wardens of the Catalan, Aragonese and French environmental public agencies and from the Pyrenean protected areas of Aigüestortes i Estany de Sant Maurici 
National Park, Pyrénées National Park, Alt Pirineu Natural Park, Posets-Maladeta Natural Park and Valles Occidentales Natural Park. David O'Brien and Jeanette Hall kindly assisted in editing the manuscript and made useful suggestions. Economic support was provided by the Spanish Government projects Fundalzoo (CGL201014841) and Invasivefish (427/2011) and by the European Commission LIFE+ project LimnoPirineus (LIFE13 NAT/ES/001210).

\section{Appendix A. Supplementary data}

Supplementary data to this article can be found online at http://

\section{References}

Baddeley, A., Rubak, E., Turner, R., 2015. Spatial Point Patterns: Methodology and Applications with R. Chapman and Hall/CRC Press, London.

Benard, M.F., Fordyce, J.A., 2003. Are induced defenses costly? Consequences of predator-induced defenses in western toads, Bufo boreas. Ecology 84, 68-78.

Christenson, D.P., 1977. History of trout introductions in California high mountain lakes, In A Symposium on the Management of High Mountain Lakes in California's National Parks. pp. 9-15.

Crump, M.L., Scott Jr., N.J., 1994. Visual encounter surveys, In Measuring and monitoring biological diversity: standard methods for amphibians. eds W.R. Heyer, M.A. Donnelly, R.W. McDiarmid, L.-A.C. Hayek, M.S. Foster, pp. 8491. Smithsonian Institution Press, Washington, DC.

Davidson, C., Knapp, R.A., 2007. Multiple stressors and amphibian declines: Dual impacts of pesticides and fish on yellow-legged frogs. Ecol. Appl. 17, 587-597.

Delacoste, M., Baran, P., Lascaux, J.M., Abad, N., Besson, J.P., 1997. Evaluation of salmonid introductions in high-elevation lakes and streams of the HautesPyrenees region. Bull. Fr. Peche Piscic., 205-219.

Denoël, M., Dzukic, G., Kalezic, M.L., 2005. Effects of widespread fish introductions on paedomorphic newts in Europe. Conserv. Biol. 19, 162-170.

European Council, 1992. Directive 92/43/EEC of the Council of the European Communities of 21 May 1992 on the conservation of natural habitats and of wild fauna and flora, http://eur-lex.europa.eu/legalcontent/EN/ALL/?uri=CELEX:01992L0043-20070101 Accessed 27 March 2017.

Fife, D., 2017. fifer: A biostatisticians toolbox for various activities, including plotting, data cleanup, and data analysis. $\mathrm{R}$ package version 1.1. https://CRAN.Rproject.org/package $=$ fifer.

Finlay, J.C., Vredenburg, V.T., 2007. Introduced trout sever trophic connections in watersheds: consequences for a declining amphibian. Ecology 88, 2187-2198. 
Fischer, J., Lindenmayer, D.B., 2007. Landscape modification and habitat fragmentation: a synthesis. Glob. Ecol. Biogeogr. 16, 265-280.

Griffiths, R.A., Williams, C., 2000. Modelling population dynamics of great crested newts (Triturus cristatus): a population viability analysis. Herpetol. J. 10, 157163.

Häkkinen, J., Pasanen, S., Kukkonen, J.V.K., 2001. The effects of solar UV-B radiation on embryonic mortality and development in three boreal anurans (Rana temporaria, Rana arvalis and Bufo bufo). Chemosphere 44, 441-446.

Hardie, S.A., Jackson, J.E., Barmuta, L.A., White, R.W.G., 2006. Status of galaxiid fishes in Tasmania, Australia: conservation listings, threats and management issues. Aquat. Conserv. 16, 235-250.

Hartel, T., Nemes, S., Oellerer, K., Cogalniceanu, D., Moga, C., Arntzen, J.W., 2010. Using connectivity metrics and niche modelling to explore the occurrence of the northern crested newt Triturus cristatus (Amphibia, Caudata) in a traditionally managed landscape. Environ. Conserv. 37, 195-200.

Hastie, T., Tibshirani, R., 1990. Generalised Additive Models. Chapman \& Hall, London - Weinheim - New York - Tokyo - Melbourne - Madras.

Indermaur, L., Schaub, M., Jokela, J., Tockner, K., Schmidt, B.R., 2010. Differential response to abiotic conditions and predation risk rather than competition avoidance determine breeding site selection by anurans. Ecography 33, 887-895.

Kenison, E.K., Litt, A.R., Pilliod, D.S., McMahon, T.E., 2016. Role of habitat complexity in predator-prey dynamics between an introduced fish and larval Long-toed Salamanders (Ambystoma macrodactylum). Can. J. Zool., 243-249.

Knapp, R.A., 2005. Effects of nonnative fish and habitat characteristics on lentic herpetofauna in Yosemite National Park, USA. Biol. Conserv. 121, 265-279.

Knapp, R.A., Corn, P.S., Schindler, D.E., 2001. The introduction of nonnative fish into wilderness lakes: good intentions, conflicting mandates, and unintended consequences. Ecosystems 4, 275-278.

Knapp, R.A., Matthews, K.R., Preisler, H.K., Jellison, R., 2003. Developing probabilistic models to predict amphibian site occupancy in a patchy landscape. Ecol. Appl. 13, 1069-1082.

Kohler, A., Sadowska, J., Olszewska, J., Trzeciak, P., Berger-Tal, O., Tracy, C.R., 2011. Staying warm or moist? Operative temperature and thermal preferences of common frogs (Rana temporaria), and effects on locomotion. Herpetol. J. 21.

Laugen, A.T., Laurila, A., Merilä, J., 2003. Latitudinal and temperature-dependent variation in embryonic development and growth in Rana temporaria. Oecologia $135,548-554$.

MacKenzie, D.I., Nichols, J.D., Lachman, G.B., Droege, S., Royle, J.A., Langtimm, C.A., 2002. Estimating site occupancy rates when detection probabilities are less than one. Ecology 83, 2248-2255. 
Maitland, P.S., Campbell, R.N., 1992. Freshwater Fishes of the British Isles. Harper Collins, London.

Marra, G., Wood, S.N., 2012. Coverage properties of confidence intervals for generalized additive model components. Scand. J. Stat. 39, 53-74.

Martínez-Rica, J.P., 1978. Los Anfibios del Alto Aragon: Un ensayo de Corología. Publicaciones del instituto de Estudios Pirenaicos.

McDowall, R.M., 1990. New Zealand Freshwater Fishes: A Natural History and Guide. Heinemann Reed.

Miró, A., Ventura, M., 2013. Historical use, fishing management and lake characteristics explain the presence of non-native trout in Pyrenean lakes: Implications for conservation. Biol. Conserv. 167, 17-24.

Miró, A., Ventura, M., 2015. Evidence of exotic trout mediated minnow invasion in Pyrenean high mountain lakes. Biol. Invasions 17, 791-803.

Montori, A., Llorente, G.A., Richter-Boix, A., 2008. Habitat features affecting the small-scale distribution and longitudinal migration patterns of Calotriton asper in a Pre-Pyrenean population. Amphibia-Reptilia 29, 371-381.

Museth, J., Borgstrom, R., Brittain, J.E., 2010. Diet overlap between introduced European minnow (Phoxinus phoxinus) and young brown trout (Salmo trutta) in the lake, vre Heimdalsvatn: a result of abundant resources or forced niche overlap? Hydrobiologia 642, 93-100.

Museth, J., Hesthagen, T., Sandlund, O.T., Thorstad, E.B., Ugedal, O., 2007. The history of the minnow Phoxinus phoxinus (L.) in Norway: from harmless species to pest. J. Fish Biol. 71, 184-195.

Orizaola, G., Braña, F., 2006. Effect of salmonid introduction and other environmental characteristics on amphibian distribution and abundance in mountain lakes of northern Spain. Anim. Conserv. 9, 171-178.

Pechlaner, R., 1984. Historical evidence fort he introduction of Arctic charr into highmountain lakes of the Alps by man, In Biology of the Arctic charr, Proceedings of the International Symposium on Arctic Charr. eds J. Johnson, B.L. Burns, pp. 449-557. University Monitoba Press, Winnipeg, Monitoba, may 1981.

Pilliod, D.S., Ricciardi, A., Hossack, B.R., Bahls, P.F., Bull, E.L., Corn, P.S., Hokit, G., Maxell, B.A., Munger, J.C., Wyrick, A., 2010. Non-native salmonids affect amphibian occupancy at multiple spatial scales. Divers. Distriv. 16, 959-974.

Pleguezuelos, J.M., Márquez, R., Lizana, M. eds., 2002. Atlas y libro rojo de los anfibios y reptiles de España. Dirección General de la Conservación de la Naturaleza-Asociación Herpetológica Española, Madrid.

Pope, K.L., Garwood, J.M., Welsh, H.H., Lawler, S.P., 2008. Evidence of indirect impacts of introduced trout on native amphibians via facilitation of a shared predator. Biol. Conserv. 141, 1321-1331. 
R Core Team, 2016. R: A Language and Environment for Statistical Computing. R Foundation for Statistical Computing, Vienna, Austria. URL http://www.Rproject.org/.

Reissig, M., Trochine, C., Queimalinos, C., Balseiro, E., Modenutti, B., 2006. Impact of fish introduction on planktonic food webs in lakes of the Patagonian Plateau. Biol. Conserv. 132, 437-447.

Schabetsberger, R., Luger, M.S., Drozdowski, G., Jagsch, A., 2009. Only the small survive: monitoring long-term changes in the zooplankton community of an Alpine lake after fish introduction. Biol. Invasions 11, 1335-1345.

Sodhi, N.S., Bickford, D., Diesmos, A.C., Lee, T.M., Koh, L.P., Brook, B.W., Sekercioglu, C.H., Bradshaw, C.J.A., 2008. Measuring the meltdown: drivers of global amphibian extinction and decline. PLoS One 3.

Suzuki, M., Tanaka, S., 2009. Molecular and cellular regulation of water homeostasis in anuran amphibians by aquaporins. Comp. Biochem. Phys. a 153, 231-241.

Thompson, R., Ventura, M., Camarero, L., 2009. On the climate and weather of mountain and sub-arctic lakes in Europe and their susceptibility to future climate change. Freshw. Biol. 54, 2433-2451.

Tiberti, R., Brighenti, S., Canedoli, C., Iacobuzio, R., Rolla, M., 2016. The diet of introduced brook trout (Salvelinus fontinalis; Mitchill, 1814) in an alpine area and a literature review on its feeding ecology. J. Limnol. 75, 488-507.

Tiberti, R., von Hardenberg, A., 2012. Impact of introduced fish on Common frog (Rana temporaria) close to its altitudinal limit in alpine lakes. Amphibia-Reptilia 33, 303-307.

Vences, M., Grossenbacher, K., Puente, M., Palanca, A., Vieites, D.R., 2003. The Cambale's fairy tale: elevational limits of Rana temporaria (Amphibia: Ranidae) and other European amphibians revisited. Folia Zool. 52, 189-202.

Walker, S.F., Bosch, J., Gomez, V., Garner, T.W.J., Cunningham, A.A., Schmeller, D.S., Ninyerola, M., Henk, D.A., Ginestet, C.E., Arthur, C.-P., Fisher, M.C., 2010. Factors driving pathogenicity vs. prevalence of amphibian panzootic chytridiomycosis in Iberia. Ecol. Lett. 13, 372-382.

Wiley, R.W., 2003. Planting trout in wyoming high-elevation wilderness waters. Fisheries 28, 22-27.

Wintle, B.A., Kavanagh, R.P., McCarthy, M.A., Burgman, M.A., 2005. Estimating and dealing with detectability in occupancy surveys for forest owls and arboreal marsupials. J. Wildlife Manage. 69, 905-917.

Wood, S.N., 2004. Stable and efficient multiple smoothing parameter estimation for generalized additive models. J. Am. Stat. Assoc. 99, 673-686.

Wood, S.N., 2006. Generalized additive models: an introduction with R. Chapman \& Hall/CRC, Boca Raton [etc].

Wood, S.N., 2008. Fast stable direct fitting and smoothness selection for generalized additive models. J. Roy. Stat. Soc. B 70, 495-518. 
Zuur, A.F., Ieno, E.N., Walker, N.J., Saveliev, A.A., Smith, G.M., 2009. Mixed effects models and extensions in ecology with R. Springer, New York. 
Tables:

\section{Table 1}

Description of environmental variables used in the analyses. See online Appendix A for

further details.

\begin{tabular}{|c|c|c|}
\hline $\begin{array}{l}\text { Variable } \\
\text { type }\end{array}$ & Variable name & Description \\
\hline \multirow[t]{2}{*}{$\begin{array}{l}\text { Non-native } \\
\text { fish }\end{array}$} & Trout presence & $\begin{array}{l}\text { Binary factor determined by the presence of introduced } \\
\text { trout in the water body }\end{array}$ \\
\hline & Minnow presence & $\begin{array}{l}\text { Binary factor determined by the presence of introduced } \\
\text { minnows in the water body }\end{array}$ \\
\hline \multirow[t]{9}{*}{ Environment } & Predation refuge & $\begin{array}{l}\text { Binary factor determined by the presence of predation } \\
\text { refuge areas from fish in the water body }\end{array}$ \\
\hline & Altitude & Altitude of the lake (m a.s.l.) \\
\hline & Surface area & Surface of the lake (ha) \\
\hline & Soft habitat PC1 & $\begin{array}{l}\text { First principal component for littoral and shore features. } \\
\text { High values are associated with shallow or flat littoral, fine } \\
\text { grain littoral substrate and vegetated shores, while low } \\
\text { values are associated with moderate to steep slope littoral, } \\
\text { coarse grain littoral substrate and bare rocky shores (Table } \\
\text { A1 in online Appendix A) }\end{array}$ \\
\hline & Aquatic vegetation & $\begin{array}{l}\% \text { coverage of the littoral occupied by submerged or } \\
\text { emergent macrophytes }\end{array}$ \\
\hline & Conductivity & Water conductivity $(\mu \mathrm{S} / \mathrm{cm})$ \\
\hline & Cold site & $\begin{array}{l}\text { Binary factor determined by the presence of cold springs or } \\
\text { late ice-snow in the water body }\end{array}$ \\
\hline & Temporary pond & $\begin{array}{l}\text { Binary factor describing if the pond dries up most of the } \\
\text { years during the ice-free season }\end{array}$ \\
\hline & Nearest pond occupied & $\begin{array}{l}\text { Distance to the nearest neighbouring occupied water body. } \\
\text { This variable was built separately for each species }\end{array}$ \\
\hline Spatial & Geographical location & $\begin{array}{l}\text { Smooth function of UTM easting and northing of the water } \\
\text { body }\end{array}$ \\
\hline
\end{tabular}




\section{Table 2}

Results of generalized additive models (GAM) developed for explaining the occurrence of each amphibian species. The sign of the association between each significant variable (except geographical location) and the probability of the species occurrence is shown in parentheses: + positive, - negative and $\cap$ positive with the centre of a unimodal curve. The increase in deviance (equivalent to variance for this type of analyses) resulting from dropping the selected variable from the model is shown also in parentheses. The percentage increases were calculated as (deviance increase/(null deviance-model deviance $\left.{ }^{\mathrm{a}}\right)$ )x100 (Knapp, 2005). "Sometimes referred to as "residual" deviance. Asterisks indicate the level of statistical significance associated with each variable: ${ }^{*} P \leq$ $0.01 ; * * P \leq 10^{-4} ; * * * P \leq 10^{-6}$; NS, not significant $(P>0.01)$. The model for Salamandra salamandra was not built due to the low number of localities where it was present, 11 of 1739 water bodies.

\begin{tabular}{|c|c|c|c|c|c|}
\hline Parameter & $\begin{array}{l}\text { Rana } \\
\text { temporaria }\end{array}$ & $\begin{array}{l}\text { Alytes } \\
\text { obstetricans }\end{array}$ & $\begin{array}{l}\text { Bufo } \\
\text { spinosus }\end{array}$ & $\begin{array}{l}\text { Calotriton } \\
\text { asper }\end{array}$ & $\begin{array}{l}\text { Lissotriton } \\
\text { helveticus }\end{array}$ \\
\hline Null deviance & 2346 & 548 & 432 & 381 & 555 \\
\hline Degrees of freedom (null model) & 1738 & 1738 & 1738 & 1738 & 1738 \\
\hline Model deviance $^{\mathrm{a}}$ & 1498 & 169 & 193 & 183 & 215 \\
\hline Degrees of freedom (full model) & 1695 & 1696 & 1707 & 1712 & 1710 \\
\hline Explained deviance (\% of total) & $36.1 \%$ & $69.2 \%$ & $55.3 \%$ & $52 \%$ & $61.2 \%$ \\
\hline$R^{2}$ adjusted & 0.42 & 0.59 & 0.34 & 0.38 & 0.47 \\
\hline \multicolumn{6}{|l|}{ Deviance increase } \\
\hline Trout presence & $176(-, 20.8)^{* * *}$ & $41(-, 10.7)^{* *}$ & $0.06(0.02)^{\mathrm{NS}}$ & $32(-, 15.9)^{* *}$ & $8(-, 2.5)^{*}$ \\
\hline Minnow presence & $60(-, 7.1)^{* * *}$ & $0.04(0.01)^{\mathrm{NS}}$ & $0.0(0.0)^{\mathrm{NS}}$ & $0.0(0.0)^{\mathrm{NS}}$ & $4(1.2)^{\mathrm{NS}}$ \\
\hline Predation refuge & $18(+, 2.1)^{* *}$ & $15(+, 3.9)^{*}$ & $0.0(0.0)^{\mathrm{NS}}$ & $17(+, 8.6)^{*}$ & $2(0.7)^{\mathrm{NS}}$ \\
\hline Altitude & $25(\cap, 2.9)^{* *}$ & $33(-, 8.8)^{*}$ & $42(-, 17.7)^{* * *}$ & $3(1.4)^{\mathrm{NS}}$ & $37(-, 10.8)^{* *}$ \\
\hline Surface area & $39(-, 4.6)^{*}$ & $11(2.9)^{\mathrm{NS}}$ & $28(11.9)^{\mathrm{NS}}$ & $33(\cap, 16.7)^{* *}$ & $15(\cap, 4.3)^{*}$ \\
\hline Soft habitat PC1 & $63(+, 7.5)^{* * *}$ & $13(3.4)^{\mathrm{NS}}$ & $20(8.3)^{\mathrm{NS}}$ & $21(-, 10.6)^{* *}$ & $15(4.5)^{\mathrm{NS}}$ \\
\hline Aquatic vegetation & $14(1.7)^{\mathrm{NS}}$ & $6(1.5)^{\mathrm{NS}}$ & $0.5(0.2)^{\mathrm{NS}}$ & $0.0(0.0)^{\mathrm{NS}}$ & $7(2.01)^{\mathrm{NS}}$ \\
\hline Water conductivity & $0.2(0.02)^{\mathrm{NS}}$ & $66(+, 17.5)^{* * *}$ & $2(0.8)^{\mathrm{NS}}$ & $30(\cap, 15.2)^{*}$ & $20(5.9)^{\mathrm{NS}}$ \\
\hline Cold site & $87(-, 10.3)^{* * *}$ & $8(-, 2.1)^{\mathrm{NS}}$ & $6(2.5)^{\mathrm{NS}}$ & $0.0(0.0)^{\mathrm{NS}}$ & $0.0(0.0)^{\mathrm{NS}}$ \\
\hline Temporary pond & $5(0.5)^{\mathrm{NS}}$ & $42(11.1)^{*}$ & $0.0(0.0)^{\mathrm{NS}}$ & $0.0(0.0)^{\mathrm{NS}}$ & $0.0(0.0)^{\mathrm{NS}}$ \\
\hline Nearest pond occupied & $38(-, 4.4) * * *$ & $65(-, 17.1)^{* *}$ & $56(-, 23.6)^{* *}$ & $20(-, 10.1)^{*}$ & $26(-, 7.5)^{*}$ \\
\hline Geographical location & $44(5.2)^{*}$ & $85(22.5)^{* * *}$ & $19(8.1)^{\mathrm{NS}}$ & $8(3.9)^{\mathrm{NS}}$ & $0.0(0.0)^{\mathrm{NS}}$ \\
\hline
\end{tabular}




\section{Figures}

Fig. 1. Distribution of studied lakes along the Pyrenean range with the presence or absence of non-native fish, either trout or minnows and the different amphibian species found in the Pyrenean water bodies.

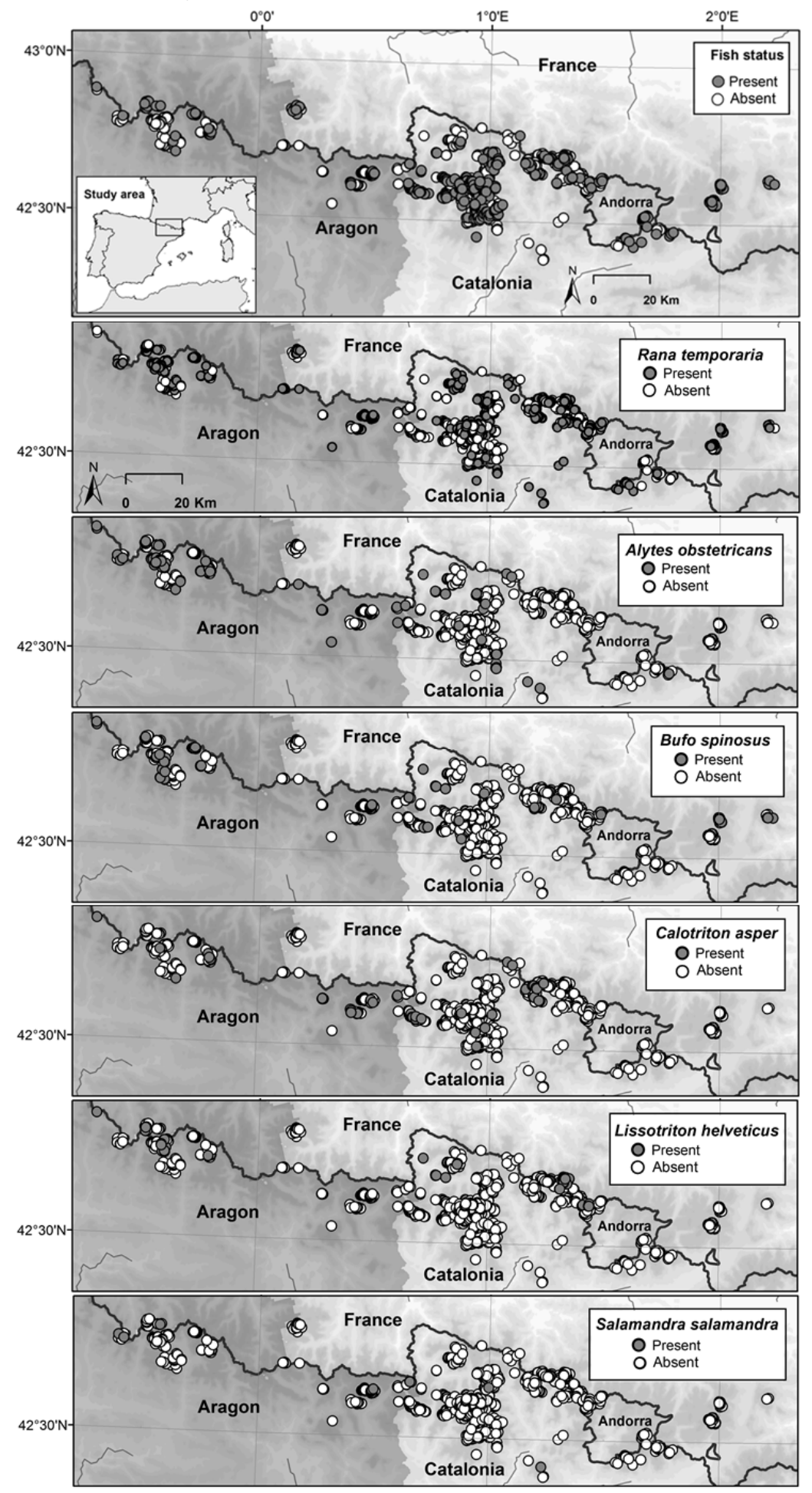


Fig. 2. Percentage of water bodies where amphibian species were found grouped in four categories: fishless, only trout presence, trout + minnow presence, and only minnow presence. The absolute number of presences is indicated above the bars and between brackets. The total number of water bodies in each category is indicated in the legend. The total number of water bodies where each species was found is indicated below the species name. $p$ values of the chi-square tests are also indicated. For the species with significant $p$ values $(<0.05)$, the differences between categories obtained by post hoc chi square tests corrected for multiple testing by Bonferroni method $(\alpha=0.05)$ are also indicated.

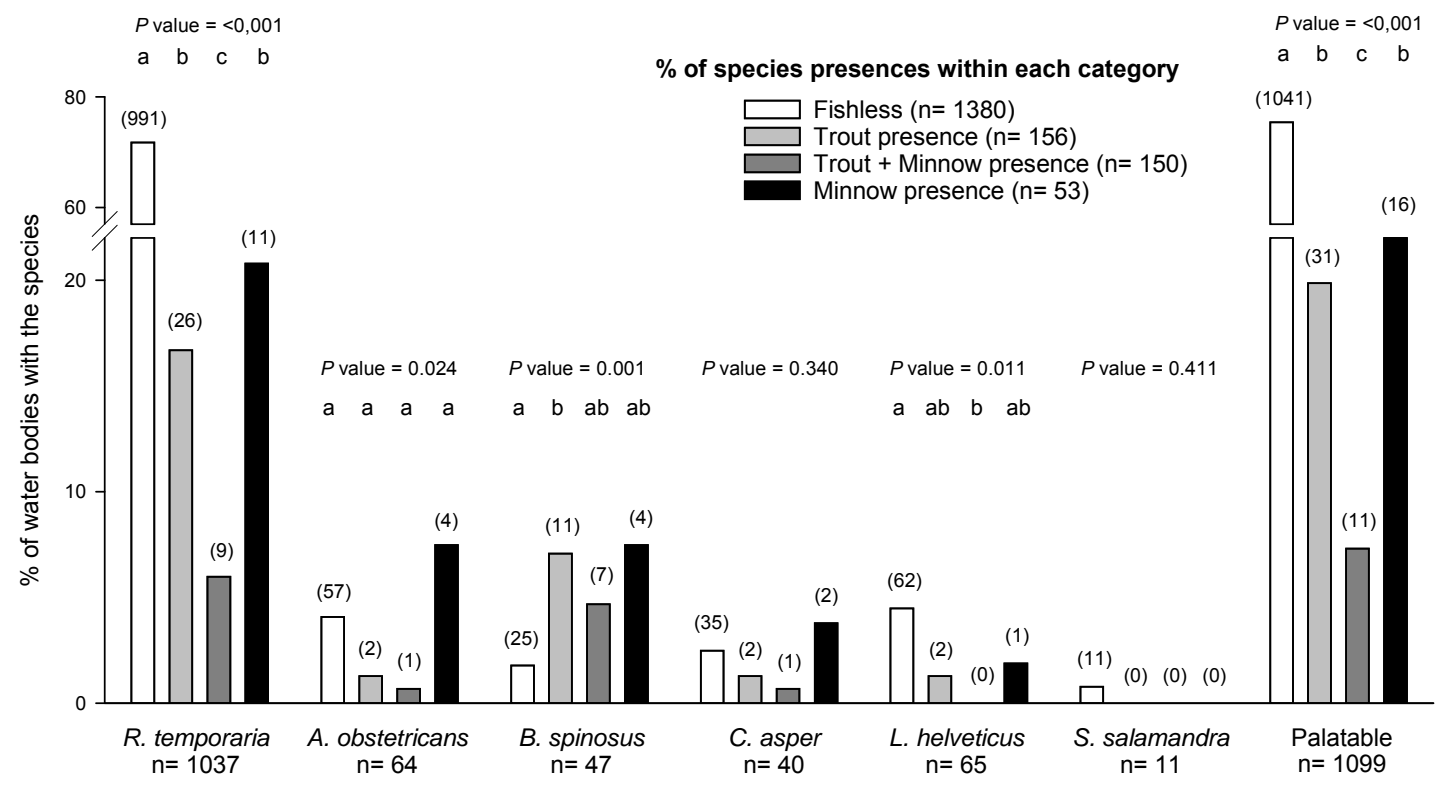


Fig. 3 (next page). Estimated effect of each of the highly significant variables $(p<$ 0.01 ) on the probability of occurrence of the anurans Rana temporaria (a), Alytes obstetricans (b) and Bufo spinosus (c), obtained with the generalized additive models (GAM). The contour of the shaded areas and the error dashed lines are approximately $+/-2 \mathrm{SE}(95 \% \mathrm{CI})$ relative to the main estimate, and hatch marks at the bottom are a descriptor of the frequency of data points along the gradient in continuous variables, or within each category for categorical variables. The effect of UTM easting and northing is shown as an isoline map, where light grey indicates positive effect and dark grey indicates negative effect. A colour version of this isoline map is shown in Fig. A2 in the online Appendix. "edf" indicates the estimated degrees of freedom of the smooth curve: $\mathrm{df}=1$ is equivalent to a linear relationship. Smoothing parameters were estimated by general cross validation error (Wood, 2004). "D" indicates the percentage of explained deviance. Dotted grey lines in smooth terms indicates the $\mathrm{Y}$ value $=0$, allowing one to see the regions where the effect on occurrence is positive or negative. 

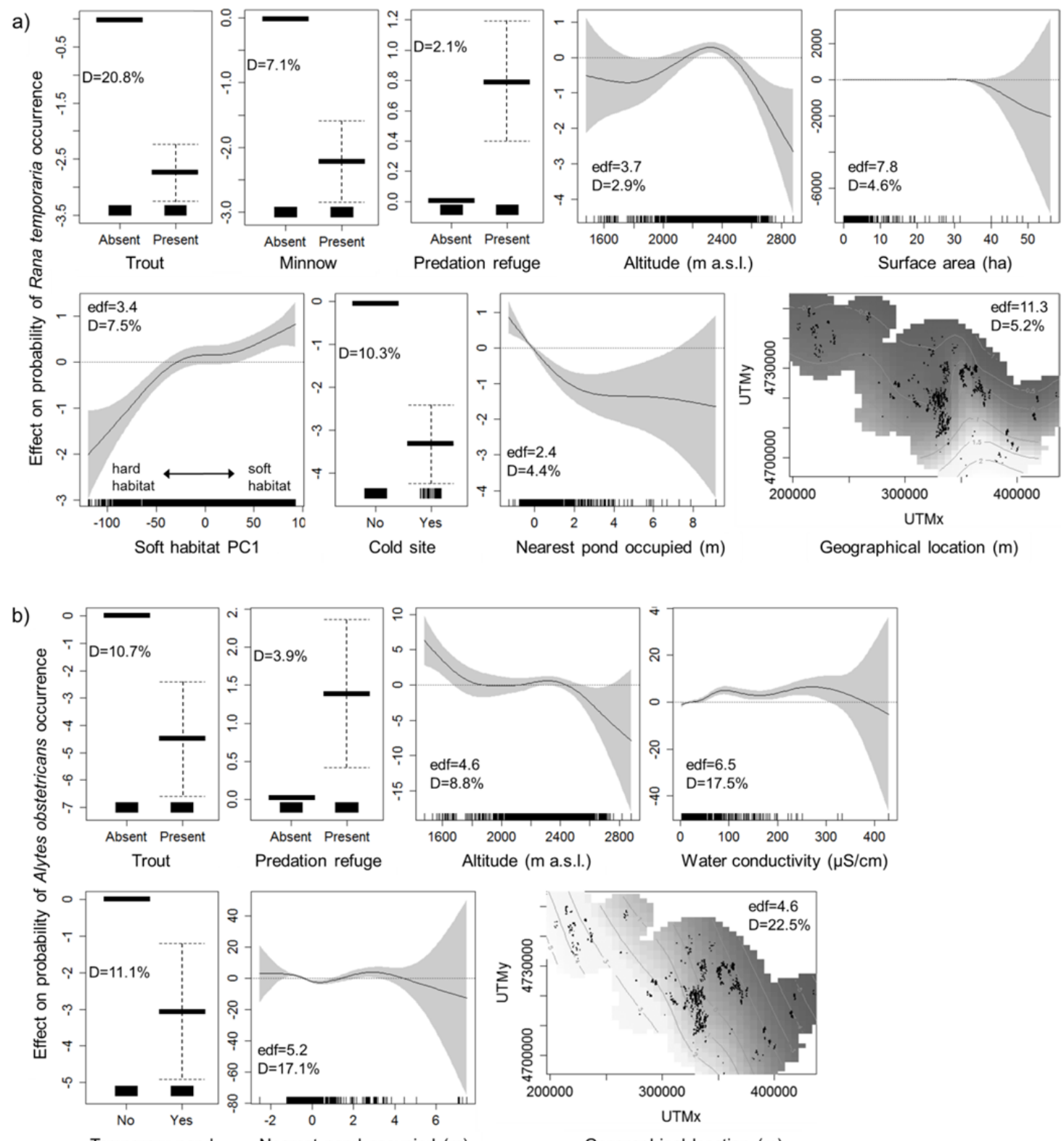

Temporary pond Nearest pond occupied (m)

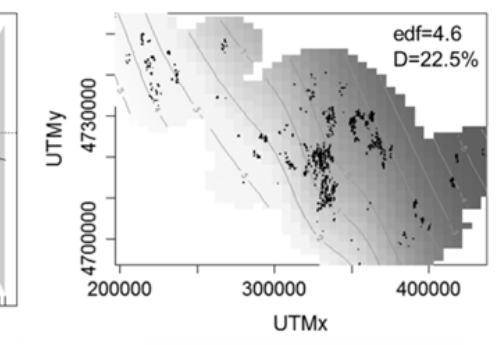

Geographical location (m)

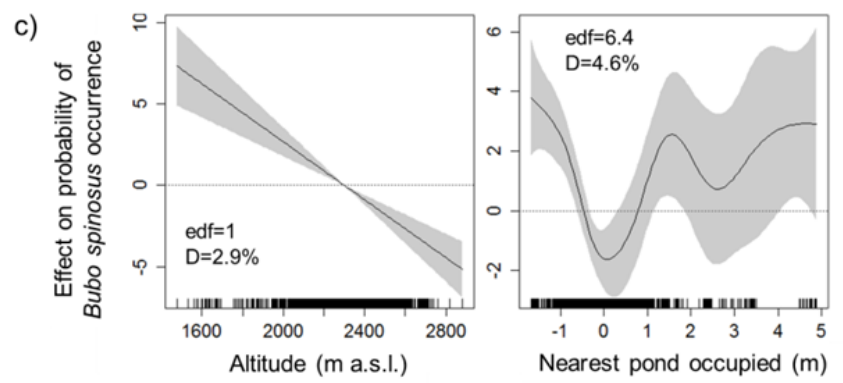


Fig. 4. Estimated effect of each of the highly significant variables $(p<0.01)$ on the probability of occurrence by the caudatans Calotriton asper (a) and Lissotriton helveticus (b), obtained with the generalized additive models (GAM). See legend of Fig. 3 for further details on the plot.

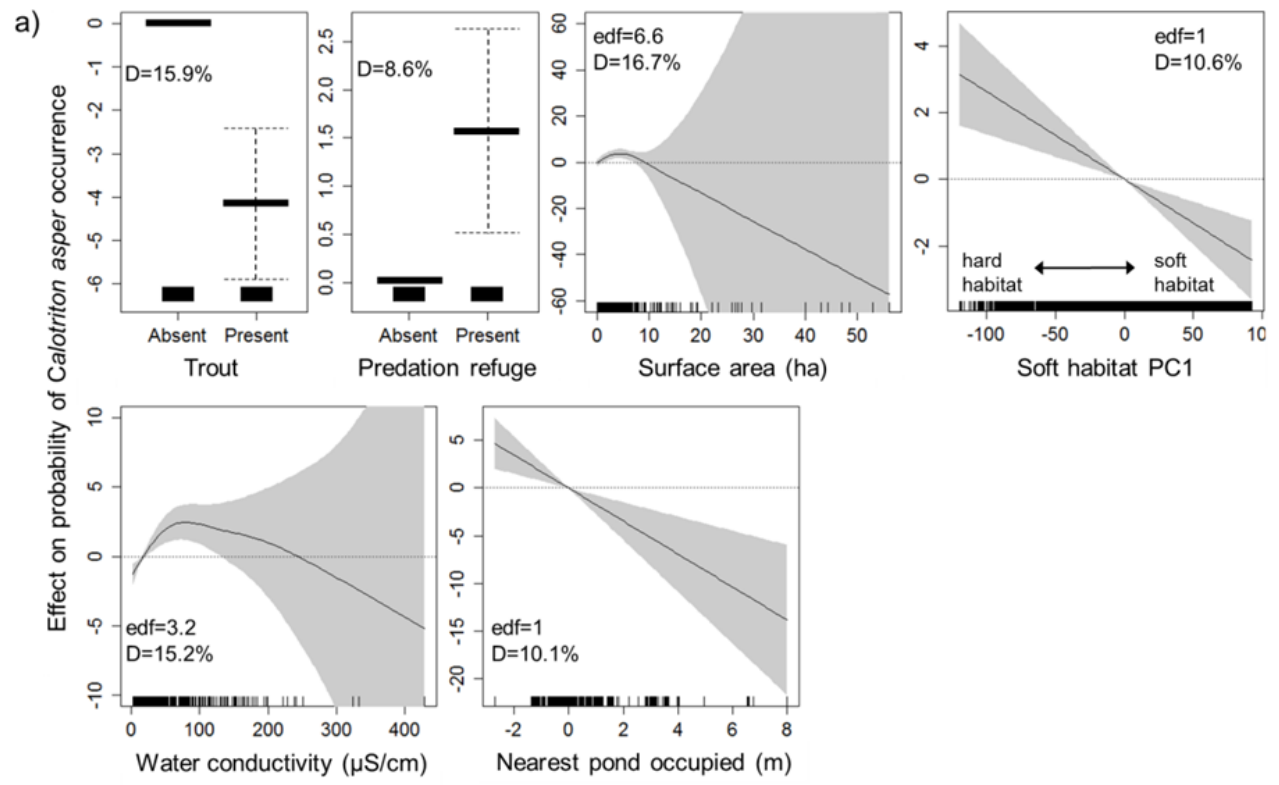

b)
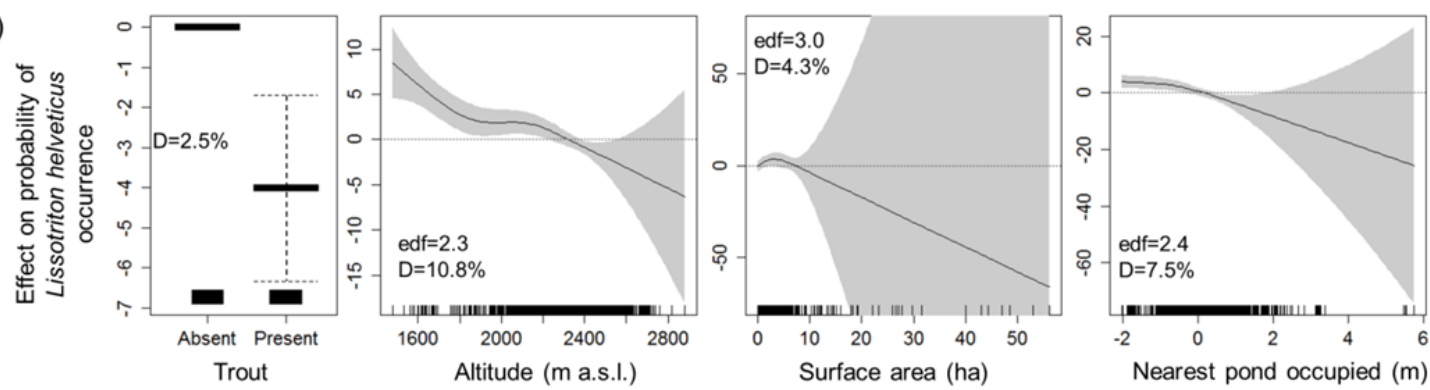


\title{
Appendix A
}

\section{Supplementary data}

Large negative effect of non-native trout and minnows on Pyrenean lake amphibians

\author{
Alexandre Miró ${ }^{a, *}$, Ibor Sabás $^{\mathrm{a}}$ and Marc Ventura ${ }^{\mathrm{a}}$ \\ ${ }^{a}$ Centre for Advanced Studies of Blanes, Spanish Research Council (CEAB-CSIC), \\ Integrative Freshwater Ecology Group (IFE), Acces Cala St. Francesc 14, Blanes \\ 17300, Girona, Catalonia, Spain. \\ *E-mail: alexestanys@gmail.com
}




\section{Supplementary materials and methods}

\subsection{Additional description of the study area}

The studied lakes and ponds are spread along the Pyrenean mountain range $\left(0^{\circ} 42^{\prime} \mathrm{W}\right.$ $2^{\circ} 09^{\prime} \mathrm{E}, 42^{\circ} 52^{\prime}-42^{\circ} 23^{\prime} \mathrm{N}$; Fig. 1). There are 1080 lakes $>0.5$ ha and approximately 4500 small lakes and ponds either of glacial origin or modified by the activity of quaternary glaciations. They range in altitude between 1500 and $2960 \mathrm{~m}$ with the highest frequency found at ca. $2300 \mathrm{~m}$. The unmodified lakes are relatively small and deep, with average surface area of 4.5 ha and average maximum depth of $15 \mathrm{~m}$, with the largest being 44 ha and the deepest $105 \mathrm{~m}$. Approximately $15 \%$ of the total lakes are impounded, mostly the biggest. Among these semi-natural dammed lakes, the largest has an area of 160 ha and the deepest a maximum depth of 123 . The ponds can range in surface area from between a few square meters to 0.5 ha, and in maximum depth from between a few centimetres to 1-2 $\mathrm{m}$. Some of them are temporary and may dry up in the peak of the ice-free season.

Due to their common glacial origin, there is a close positive relationship between surface area and maximum depth (Catalan et al., 2009b). Most of the lakes are above the tree line with catchments partially covered by meadows, although some of them are on or below the tree line. Approximately half of the lakes have catchments on granodiorite bedrock, the remaining being located in catchments with metamorphic (25\%), detrital $(15 \%)$ or carbonate $(10 \%)$ bedrock, with a minority on Silurian slate (Casals-Carrasco et al., 2009). The latter bedrocks, due to their high sulphate content, give natural acidity to the waters $(\mathrm{pH}<5.5)$. The ionic content is generally low, being the chemical factor most strongly related to bedrock composition (Catalan et al., 1993). The lakes have low phosphorous and chlorophyll content, being of oligotrophic nature (Buchaca and Catalan, 2007). A general description of the climate, physic-chemical and biological characteristics of Pyrenean lakes and a comparison with other European high mountain lakes can be found elsewhere (Camarero et al., 2009; Catalan et al., 2009a; Kernan et al., 2009; Thompson et al., 2009).

\subsection{Detailed description of the environmental variables}

We generated a set of descriptors (Table 1 in the main body of the paper) summarizing the environmental characteristics of the studied water bodies as follows.

Altitude, lake surface area and geographical coordinates easting and northing of the water bodies were obtained from a GIS generated from 1:25000 maps from various governmental agencies (Casals-Carrasco et al., 2009). 
Littoral slope and littoral and shore habitats were characterized by visually estimating substrate features and composition of the same shore segments where we had looked for amphibians (see Study area and amphibian survey section, in the main body of the paper). Data were expressed as \% coverage for each category of littoral slope and shore substrate composition. Littoral slope was categorized as shallow $\left(<10 \mathrm{~cm}\right.$ deep, $<15^{\circ}$ slope), slight slope $\left(15^{\circ}-30^{\circ}\right.$ slope $)$, sloping $\left(30^{\circ}-70^{\circ}\right.$ slope $)$ or sub vertical $\left(70^{\circ}-90^{\circ}\right.$ slope). Littoral substrate composition was categorized as organic material, silt-sand $(<0.5 \mathrm{~cm})$, gravel $(>0.5-2.5 \mathrm{~cm})$, cobble $(>2.5-25 \mathrm{~cm})$, boulder $(>25 \mathrm{~cm}-1 \mathrm{~m})$, big boulder $(>1 \mathrm{~m})$ or bedrock. Shore substrate composition was categorized as cobbleboulder $(2.5 \mathrm{~cm}-1 \mathrm{~m})$, big boulder-bedrock $(>1 \mathrm{~m})$ or terrestrial vegetation. We adapted these classifications from previous studies of high mountain and boreal lake fauna (e.g. Johnson et al., 2004; Knapp, 2005; Knapp et al., 2003; Knapp et al., 2001). To reduce the dimensionality of those data, we subjected to a principal component analysis the six most contrasted categories: shallow or flat littoral ( $<10 \mathrm{~cm}$ deep, $<15^{\circ}$ slope), moderate to steep slope littoral $\left(30^{\circ}-70^{\circ}\right.$ slope $)$, littoral substrate categories of silt-sand $(<0.5 \mathrm{~cm})$ and boulder $(>25 \mathrm{~cm}-1 \mathrm{~m})$, and shore substrate categories of cobble-boulder $(2.5 \mathrm{~cm}-1$ $\mathrm{m})$ and terrestrial vegetation. Axis 1 explained a substantial amount of the total variation in substrate and shore habitat characteristics (57.4\%), so the scores were used as the independent variable soft habitat $\mathrm{PC} 1$. High values of this variable were associated with shallow or flat slope littoral, fine grain littoral substrate and vegetated shores, while low values were associated with moderate to steep slope littoral, coarse grain littoral substrate and bare rocky shores (Table A1 in this online Appendix A).

The binary variable predation refuge was created to reflect the presence of littoral areas in the lake where fish was assumed to be unable to access: shallow areas either with or without macrophytes and stones.

Aquatic vegetation was assessed by estimating the percentage cover of submerged or emergent macrophytes along the littoral of the lakes.

Conductivity, referred to $20^{\circ} \mathrm{C}$, was measured during field surveying with handheld meter WTW Cond 340i.

To describe extreme thermal characteristics of the water studied bodies, we made a binary variable to highlight the sites with cold water inflow throughout the summer, and that have as a result a lower water temperature than expected by their altitude. This binary categorical variable was determined by the presence of cold springs or late ice/snow in the water body during summer.

We also assessed the duration of the hydroperiod and we categorized the existence of temporary ponds when they dry up almost annually, during most of the ice-free seasons. 
A measure of connectivity among the studied water bodies was computed as the distance to the nearest neighbouring water body occupied by a given species. This connectivity indicator has shown to be equally powerful than more complex indices and more practical for many conservation applications (Prugh, 2009), specifically for amphibians in fragmented landscapes (Hartel et al., 2010). The variable was generated separately for each amphibian species using R statistical software (R Core Team, 2016) with the package spatstat (Baddeley et al., 2015). Then the values were corrected for the heterogeneous effect of the Pyrenean geology on the density of water bodies by standardizing the values to zero mean and unit variance within each geology type. The geology types were adopted from Casals-Carrasco et al. (2009). The distance to the nearest neighbouring occupied water body was computed without imposing any catchment restriction, since genetic analysis show that the phylogenetic structure of amphibian populations in the Pyrenees despite having a strong spatial pattern, it does not follow strict hydrological basins (e.g. Gonçalves et al., 2015; Veith et al., 2002).

\section{Supplementary references}

Baddeley, A., Rubak, E., Turner, R., 2015. Spatial Point Patterns: Methodology and Applications with R. Chapman and Hall/CRC Press, London.

Buchaca, T., Catalan, J., 2007. Factors influencing the variability of pigments in the surface sediments of mountain lakes. Freshw. Biol. 52, 1365-1379.

Camarero, L., Rogora, M., Mosello, R., Anderson, N.J., Barbieri, A., Botev, I., Kernan, M., Kopacek, J., Korhola, A., Lotter, A.F., Muri, G., Postolache, C., Stuchlik, E., Thies, H., Wright, R.F., 2009. Regionalisation of chemical variability in European mountain lakes. Freshw. Biol. 54, 2452-2469.

Casals-Carrasco, P., Ventura, M., Gond, V., Madhavan, B., Pretus, J., Catalan, J., 2009. A spectral approach to satellite land cover classification of European remote mountain lake districts. Arch. Hydrobiol. - Adv. Limnol. 62, 353-365.

Catalan, J., Ballesteros, E., Gacia, E., Palau, A., Camarero, L., 1993. Chemical composition of disturbed and undisturbed high-mountain lakes in the Pyrenees: a reference for acidified sites. Water Research 27, 133-141.

Catalan, J., Barbieri, M.G., Bartumeus, F., Bitusik, P., Botev, I., Brancelj, A., Cogalniceanu, D., Garcia, J., Manca, M., Marchetto, A., Ognjanova-Rumenova, N., Pla, S., Rieradevall, M., Sorvari, S., Stefkova, E., Stuchlik, E., Ventura, M., 
2009a. Ecological thresholds in European alpine lakes. Freshw. Biol. 54, 24942517.

Catalan, J., Curtis, C.J., Kernan, M., 2009b. Remote European mountain lake ecosystems: regionalisation and ecological status. Freshw. Biol. 54, 2419-2432.

Gonçalves, H., Maia-Carvalho, B., Sousa-Neves, T., García-París, M., Sequeira, F., Ferrand, N., Martínez-Solano, I., 2015. Multilocus phylogeography of the common midwife toad, Alytes obstetricans (Anura, Alytidae): Contrasting patterns of lineage diversification and genetic structure in the Iberian refugium. Mol. Phylogenet. Evol. 93, 363-379.

Hartel, T., Nemes, S., Oellerer, K., Cogalniceanu, D., Moga, C., Arntzen, J.W., 2010. Using connectivity metrics and niche modelling to explore the occurrence of the northern crested newt Triturus cristatus (Amphibia, Caudata) in a traditionally managed landscape. Environ. Conserv. 37, 195-200.

Johnson, R.K., Goedkoop, W., Sandin, L., 2004. Spatial scale and ecological relationships between the macroinvertebrate communities of stony habitats of streams and lakes. Freshw. Biol. 49, 1179-1194.

Kernan, M., Ventura, M., Brancelj, A., Clarke, G., Raddum, G., Stuchlík, E., Catalan, J., 2009. Regionalisation of remote European mountain lake ecosystems according to their biota: environmental versus geographical patterns. Freshw. Biol. 54, 2470-2493.

Knapp, R.A., 2005. Effects of nonnative fish and habitat characteristics on lentic herpetofauna in Yosemite National Park, USA. Biol. Conserv. 121, 265-279.

Knapp, R.A., Matthews, K.R., Preisler, H.K., Jellison, R., 2003. Developing probabilistic models to predict amphibian site occupancy in a patchy landscape. Ecol. Appl. 13, 1069-1082.

Knapp, R.A., Matthews, K.R., Sarnelle, O., 2001. Resistance and resilience of alpine lake fauna to fish introductions. Ecol. Monogr. 71, 401-421.

Prugh, L.R., 2009. An Evaluation of Patch Connectivity Measures. Ecol. Appl. 19, 1300-1310.

R Core Team, 2016. R: A Language and Environment for Statistical Computing. R Foundation for Statistical Computing, Vienna, Austria. URL http://www.Rproject.org/. 
Thompson, R., Ventura, M., Camarero, L., 2009. On the climate and weather of mountain and sub-arctic lakes in Europe and their susceptibility to future climate change. Freshw. Biol. 54, 2433-2451.

Veith, M., Vences, M., Vieites, D.R., Nieto-Roman, S., Palanca, A., 2002. Genetic differentiation and population structure within the Spanish common frogs (Rana temporaria complex; Ranidae, Amphibia). Folia Zool. 51, 307-318.

Wintle, B.A., Kavanagh, R.P., McCarthy, M.A., Burgman, M.A., 2005. Estimating and dealing with detectability in occupancy surveys for forest owls and arboreal marsupials. J. Wildlife Manage. 69, 905-917.

\section{Supplementary tables}

\section{Table A1}

Pearson's correlations between the variables describing the litoral substrate and the principal component axis 1 . The variance contained in the first axis is given between brackets and above the correlations (\% explained variance).

\begin{tabular}{lll}
\hline \multirow{2}{*}{ Soft habitat PC1 } & Axis 1 & \multicolumn{1}{c}{ Sig. } \\
\cline { 2 - 3 } & $(57.4 \%$ explained variance $)$ \\
\hline Littoral slope & & \\
Shallow or flat $\left(<10 \mathrm{~cm}\right.$ deep, $<15^{\circ}$ slope $)$ & 0.83 & $<0.001$ \\
Moderate to steep slope $\left(30^{\circ}-70^{\circ}\right.$ slope $)$ & -0.71 & $<0.001$ \\
& & \\
Littoral substrate & & $<0.001$ \\
Silt-sand $(<0.5 \mathrm{~cm})$ & 0.81 & $<0.001$ \\
Boulder $(>25 \mathrm{~cm})$ & -0.71 & \\
& & $<0.001$ \\
Shore substrate & & $<0.001$ \\
Terrestrial vegetation & 0.69 & \\
Cobble-boulder $(2.5 \mathrm{~cm}-1 \mathrm{~m})$ & -0.63 & \\
\hline
\end{tabular}




\section{Table A2}

Variance Inflation Factors (VIF) of the datasets used in the GAM analyses. The values are given separately for each species, since the variable nearest pond occupied was calculated specifically for each taxon.

\begin{tabular}{llllll}
\hline \multirow{2}{*}{ Variable } & \multicolumn{6}{l}{ VIF values for each specific dataset } \\
\cline { 2 - 6 } & $\begin{array}{l}\text { Rana } \\
\text { temporaria }\end{array}$ & $\begin{array}{l}\text { Alytes } \\
\text { obstetricans }\end{array}$ & $\begin{array}{l}\text { Bufo } \\
\text { spinosus }\end{array}$ & $\begin{array}{l}\text { Calotriton } \\
\text { asper }\end{array}$ & $\begin{array}{l}\text { Lissotriton } \\
\text { helveticus }\end{array}$ \\
\hline Trout presence & 1.67 & 1.68 & 1.67 & 1.68 & 1.67 \\
Minnow presence & 1.59 & 1.59 & 1.60 & 1.59 & 1.59 \\
Predation refuge & 1.27 & 1.27 & 1.27 & 1.28 & 1.28 \\
Altitude & 2.00 & 2.02 & 2.03 & 2.00 & 2.00 \\
Surface area & 1.34 & 1.33 & 1.33 & 1.33 & 1.33 \\
Soft habitat PC1 & 1.72 & 1.68 & 1.68 & 1.67 & 1.67 \\
Aquatic vegetation & 1.27 & 1.27 & 1.28 & 1.28 & 1.27 \\
Water conductivity & 1.30 & 1.32 & 1.32 & 1.33 & 1.34 \\
Cold site & 1.02 & 1.02 & 1.02 & 1.02 & 1.02 \\
Temporary pond & 1.19 & 1.20 & 1.20 & 1.19 & 1.20 \\
Nearest pond occupied & 1.09 & 1.37 & 1.07 & 1.34 & 1.32 \\
Coordinate UTMx & 1.55 & 1.94 & 1.56 & 1.89 & 1.55 \\
Coordinate UTMy & 1.81 & 1.79 & 1.79 & 1.80 & 2.04 \\
\hline
\end{tabular}




\section{Supplementary figures}

a) Rana temporaria

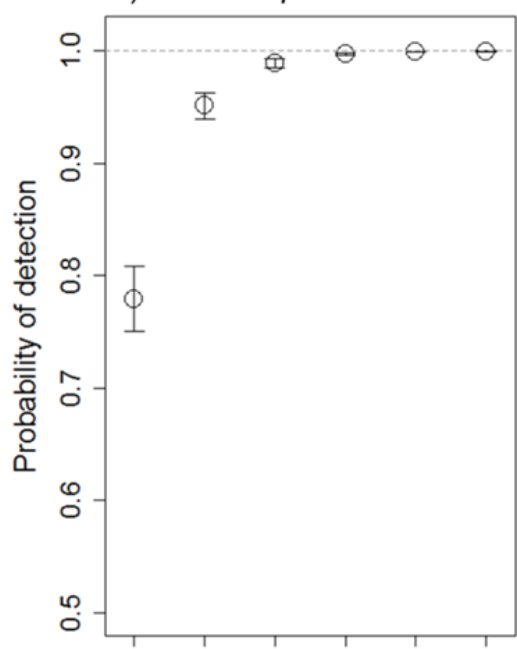

d) Calotriton asper

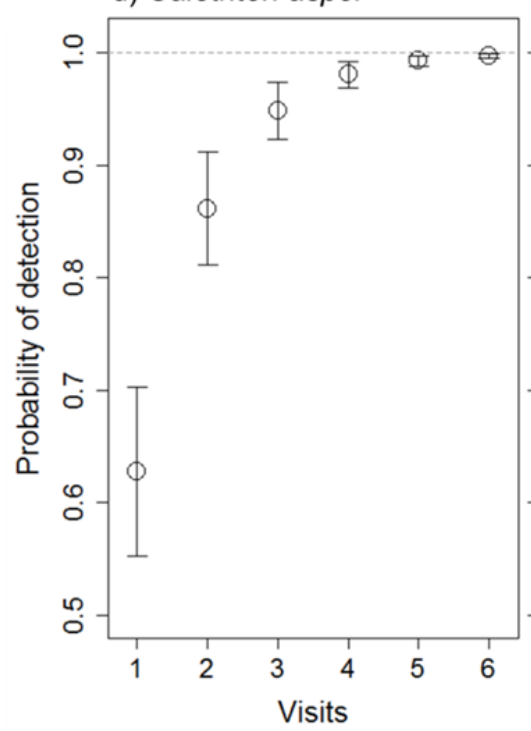

b) Alytes obstetricans

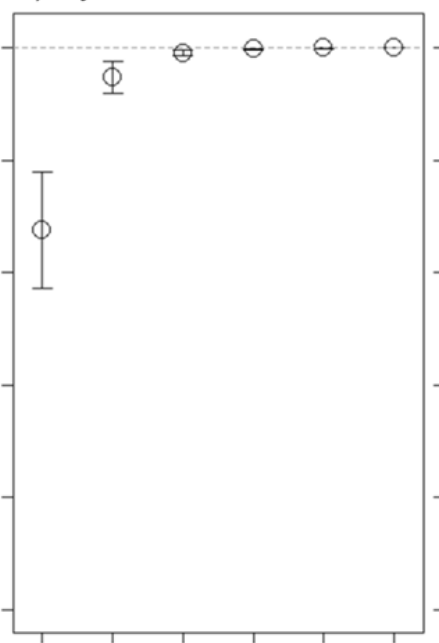

e) Lissotriton helveticus

Lissotriton helveticus

c) Bufo spinosus

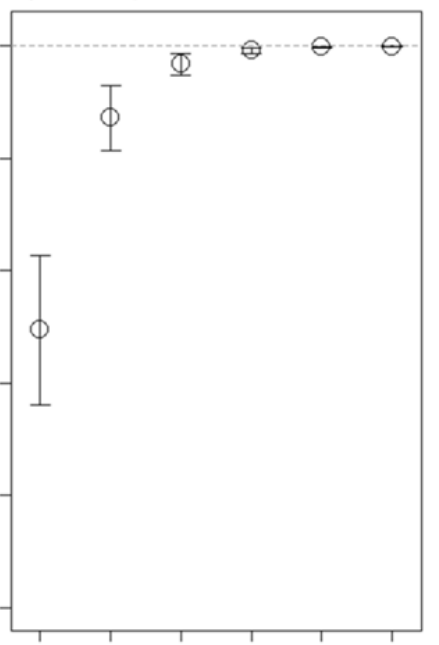

f) Salamandra salamandra

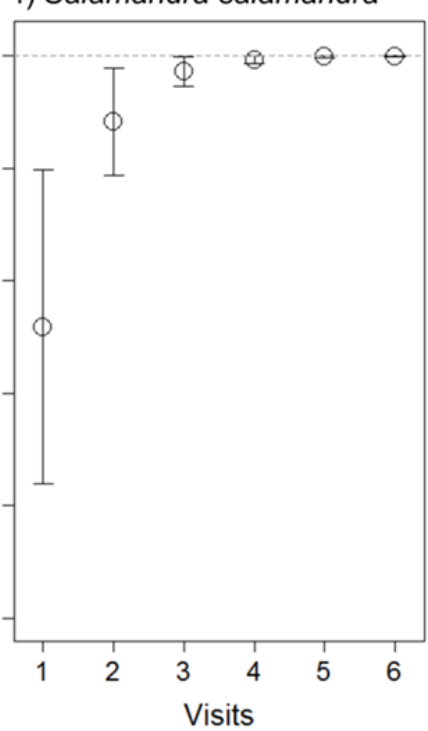

Fig. A1. Detectability curves for the 6 amphibian species found in the Pyrenean high mountain lakes computed following Wintle et al. (2005): Rana temporaria (a), Alytes obstetricans (b), Bufo spinosus (c), Calotriton asper (d), Lissotriton helveticus (e) and Salamandra salamandra (f). The graphics show the accumulated probability of detecting a given a species in a water body when the number of visits increase and the species is present, assuming that the probability of detection is the same at all visits and that the detections are independent among visits. Error bars indicate the $95 \%$ confidence intervals (CI). Horizontal grey dotted lines indicate the probability of detection equal to one. 
a)

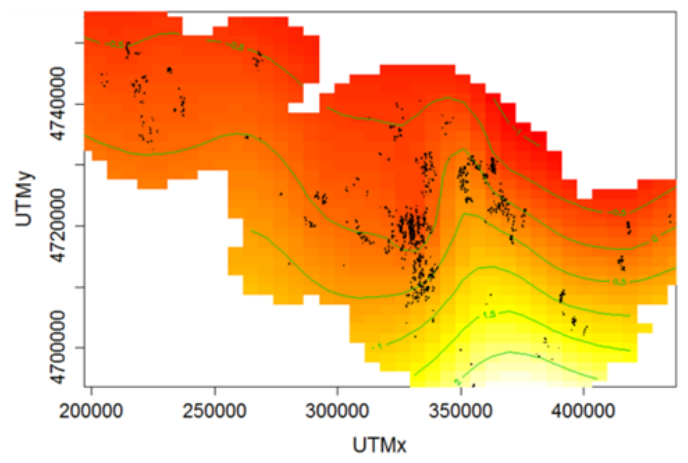

b)

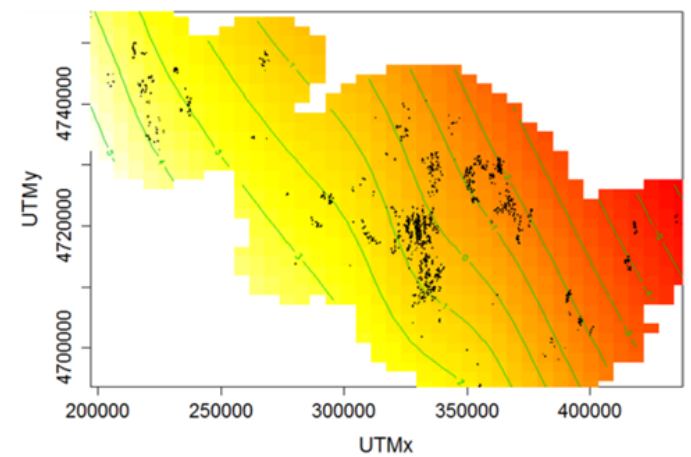

Fig. A2 Colour version of the GAM isoline maps for the estimated effect of the highly significant $(P \leq$ 0.01) smoothing term UTM easting and northing on the occurrence of: Rana temporaria (a) and Alytes obstetricans (b). Yelow colour indicates positive effect and red colour indicates negative effect on the probability of species occurrence. 